\title{
Verbal Rating Scale 6-Point
}

National Cancer Institute

\section{Source}

National Cancer Institute. Verbal Rating Scale 6-Point. NCI Thesaurus. Code C158273.

A type of verbal rating scale composed of 6 items. 